\title{
Glucose or Essential Amino Acid Infusions in Late Pregnant and Early Lactating Simmenthal Cows Failed to Induce a Leptin Response
}

\author{
G. Gabai ${ }^{1,3}$, G. Cozzi ${ }^{1}$, F. Rosi ${ }^{2}$, I. Andrighetto ${ }^{1}$ and G. Bono ${ }^{1}$
}

Addresses of authors: ${ }^{1}$ Dipartimento di Scienze Zootecniche, Facoltà di Medicina Veterinaria, Università di Padova, Agripolis, 35020 Legnaro (PD), Italy; ${ }^{2}$ Istituto di Zootecnia Generale, Facoltà di Agraria, Università di Milano, via Celoria, 2, 20133 Milano, Italy; ${ }^{3}$ Corresponding author: E-mail: gianfranco.gabai@unipd.it

With 6 tables and one figure

Received for publication January 25, 2001

\section{Summary}

To assess the leptin response to metabolic challenges, three Italian Simmental cows were infused for $6 \mathrm{~h}$ : with (a) saline (control); (b) glucose; and (c) amino acid solutions according to a $3 \times 3$ Latin square experiment. The infusions were carried out at the 36th week of pregnancy, and the second and 12th week of the following lactation. At each of the three infusion periods, blood samples were collected from the jugular vein before and $15,30,120,180,240,300$ and 360 min after the beginning of each infusion. All samples were analysed for leptin, insulin, glucagon, growth hormone $(\mathrm{GH})$, glucose, non-esterified fatty acids (NEFA) and urea. The physiological phase of the cows significantly affected the basal concentrations of insulin, glucagon, urea and NEFA. The infusion of both glucose and the amino acid solutions did not affect leptin concentrations. Insulin response was significantly increased when animals were infused with the glucose solution and, within treatment, the greatest response was observed at the 12th week of lactation. The greatest glucagon response was observed when infusing the amino acid solution. Urea response to all treatments increased from the dry period to the 12th week of lactation. The GH and NEFA responses were not affected by treatments. The Multi Species radio-immunoassay used in this study showed a lower sensitivity for ruminant leptin which may partially explain the lack of significant leptin variations. However, it can be hypothesized that leptin variations around parturition can be affected by the negative energy balance, and leptin release is not acutely affected by glucose and amino acid availability. In addition, no short-term relationship were found between insulin, glucagon and $\mathrm{GH}$ and leptin release in Italian Simmental cows during the dry period and early lactation.

\section{Introduction}

Nutritional strategies to meet the nutrient requirements of the lactating cow should be based on a complete understanding of the metabolic adaptations of the animals during the transition from the dry period to early lactation. Such adaptations depend on the different sensitivity of the extra-mammary tissues to metabolic hormones as well as on the variation of the circulating levels of these hormones, which are influenced by both the negative energy balance and the variation of the sensitivity of the endocrine tissues towards circulating metabolites (Hart, 1983; Vernon, 1989).

A large body of evidence indicates leptin as one of the most important regulators of the nutritive status of animals.
However, much of the information available so far about leptin biology derived from studies performed in laboratory species and in man, whereas very few studies dealt with the regulation of leptin expression and secretion in large animals (Houseknecht et al., 1998).

Leptin is a hormone secreted by mature adipose cells into the blood and acts in the brain to reduce food intake and it is able to mediate carbohydrate and lipid metabolism acting both indirectly through the central nervous system and directly on the peripheral tissues (Houseknecht et al., 1998; Reidy and Weber, 2000). At zero energy balance, leptin expression and secretion reflect body fat mass in human, rodents (Houseknecht et al., 1998) and sheep (Delavaud et al., 2000). Recently, Ehrhardt et al. (2000) measured plasma leptin in late lactating dairy cows and found that plasma leptin varied in relation to their body condition score.

Food deprivation has been shown to significantly decrease leptin mRNA in the bovine subcutaneous adipose tissue (Tsuchiya et al., 1998) and circulating leptin in both cows (Delavaud et al., 1999) and sheep (Delavaud et al., 2000).

Much work on the acute or short-term control of leptin expression and secretion have been carried out using different animal models. Leptin displays a profound diurnal regulation, as its levels are higher at night and lower in the morning (rat: Pickavance et al., 1998; human: Havel et al., 1999; mouse: Ahren, 2000). Studies in humans suggested that the diurnal leptin variation is regulated by meals (Van Aggel-Leijssen et al., 1999) and it has been hypothesized that the mealinduced increase in circulating insulin contributes to the nocturnal rise in plasma leptin in both rats and humans (Saladin et al., 1995; Boden et al., 1996). Nevertheless, some differences in the leptin response to insulin were observed among species and administering metabolic challenges to different species produced rather controversial results.

In mice, a single injection of insulin or glucose resulted in an increase of leptin mRNA (Mizuno et al., 1996); on the contrary in humans a $4 \mathrm{~h}$ insulin infusion is required to observe an increase in plasma leptin (Malmstrom et al., 1996), whereas a $2 \mathrm{~h}$ insulin infusion was insufficient (Larsson et al., 1996). The expression of the ob gene is not acutely regulated by insulin and fasting in human abdominal subcutaneous adipose tissue (Vidal et al., 1996). In addition, glucose does not seem to modulate leptin levels (Bauman et al., 1996). Recently, Kauter et al. (2000) observed that a single injection of insulin or glucose failed to stimulate leptin release in sheep, whereas Houseknecht et al. (2000) found that insulin stimulated leptin gene expression 
in the bovine subcutaneous adipose tissue in vitro, and that the insulin effect was reduced by growth hormone (GH).

The authors are not aware of any in vivo studies on the acute regulation of leptin secretion having been performed in dairy cows and so the aim of this study was to investigate the acute response of leptin to the infusion of either glucose or a combination of essential amino acids in Italian Simmental cows during the dry period and early lactation, and to study the relationship between leptin and the other metabolic hormones.

\section{Materials and Methods}

\section{Animals and experimental design}

Three multiparous Italian Simmental cows (average milk yield during their previous lactations $5030 \pm 570 \mathrm{~kg}$ ) were randomly assigned to treatments according to a $3 \times 3$ Latin square experimental design with periods of 3 days.

The treatments consisted of a continuous intrajugular administration of saline excipient (control), glucose or amino acid solutions by a peristaltic pump (Miniplus $3^{\circledR}$; Gilson Italia, Milano, Italy). Glucose (33\% glucose solution, Upjhon, Nuova ICC, Latina, Italy) was administered in a bolus (10 g of glucose) followed by a $6 \mathrm{~h}$ infusion at the initial flow rate of $98 \mathrm{~g}$ glucose $/ \mathrm{h}$. The amino acid solution consisted of $10 \%$ (w/v) arginine (Sigma, St Louis, MO, USA), 7\% (w/v) lysine (Sigma) and $6 \%(\mathrm{w} / \mathrm{v})$ methionine (Sigma). Animals received a bolus ( $5 \mathrm{~g}$ of amino acids) followed by a $6 \mathrm{~h}$ infusion at the initial flow rate of $36 \mathrm{~g} / \mathrm{h}$. In all treatments, the flow rate of the infusion was increased every $2 \mathrm{~h}$ by $15 \%$ and the total amounts of glucose and amino acids given to the animals were 723 and $278 \mathrm{~g}$, respectively. All the infusions started at $0900 \mathrm{~h}$ and lasted $6 \mathrm{~h}$.

The animals were housed in individual tie stalls and fitted with an indwelling jugular cannula (Intraflon $2^{\circledR}$; Vigon, Ecouen, France) on the day before the beginning of the three sets of infusions. The cannula remained in situ for the duration of the infusions. The Latin square was repeated at different physiological phases of the cows, namely at the 36 th week of pregnancy (dry period), and the second and 12th weeks of lactation. Body weight was recorded at the same times.

Cows were fed daily a total mixed ration (TMR) at $0800 \mathrm{~h}$ as described in Table 1 and in the lactation phase milking occurred at 0830 and $1730 \mathrm{~h}$.

At each set of infusions, blood samples were collected from the infused jugular vein 120 and 60 min before the beginning

Table 1. Chemical composition of the diets fed to the animals. Cows received a ratio formulated for the dry period (DP) as far as the 38th week of pregnancy. During the steaming up and beginning of lactation animals were fed a diet with the ratio HY (high yielding), which was maintained as long as the milk yield was above $18 \mathrm{~kg}$ /day. During the present work, milk yield never fell below $18 \mathrm{~kg} / \mathrm{day}$

\begin{tabular}{lcc}
\hline & \multicolumn{2}{c}{ Period } \\
\cline { 2 - 3 } & Dry & Lactation \\
\hline Energy (FLU/kg DM) & 0.74 & 0.95 \\
Crude protein (\% DM) & 13.20 & 17.40 \\
NDF (\% DM) & 53.00 & 35.00 \\
Calcium (\% DM) & 0.75 & 0.65 \\
Phosphorus (\% DM) & 0.66 & 0.51 \\
\hline
\end{tabular}

NDF, neutral detergent fiber. of the infusion, just before the bolus administration (time 0 ), at $15,30,60 \mathrm{~min}$ after the bolus administration and then every hour until the end of the infusion.

The protease inhibitor aprotinin $(5000 \mathrm{KIU} / 10 \mathrm{ml}$ blood; Fluka, Chemie AG, Buchs, Switzerland) was added to blood samples in order to preserve circulating peptide hormones from attack by proteases. Blood samples were immediately centrifuged and plasma was stored at $-20^{\circ} \mathrm{C}$ until assayed for leptin, insulin, glucagon, $\mathrm{GH}$, glucose, urea and non-esterified fatty acids (NEFA). The haematocrit (PCV) was measured in blood samples collected at -120, 0, 120, 240 and 360 min from the beginning of the infusion.

All procedures were carried out within the requirements of the Italian legislation on animal care (DL n.116, 27/1/1992).

\section{Hormone and metabolite analysis}

Plasma leptin was measured by a commercial radio-immunoassay (RIA) kit (Multi Species Leptin RIA ${ }^{\circledR}$, Linco Research Inc., St. Charles, MI, USA) recommended for the cow by the manufacturer. To test the suitability of the kit for bovine leptin, a test of parallelism was performed on serial volumes (25-100 $\mu \mathrm{l})$ of bovine plasma samples $(n=4)$. As human leptin was used as the standard, plasma leptin concentrations (ng/ml) are expressed as human equivalents. The detection limit of the assay as calculated by the Riasmart software (Packard Bioscience, Milano, Italy) was $0.47 \pm 0.05 \mathrm{ng} / \mathrm{ml}$. The repeatability of the assay was assessed using human plasma as a quality control sample and the resulting coefficients of variation were $5.0 \%$ within assay and $6.0 \%$ between assays.

Plasma insulin was determined by a commercial kit (Coat-aCount insulin ${ }^{\circledR}$, Diagnostic Products Corporation, Los Angeles, CA, USA) and the procedure followed the manufacturer's instructions. The detection limit of the assay as calculated by the Riasmart software was $0.95 \pm 0.09 \mu \mathrm{U} / \mathrm{ml}$. The coefficients of variation were $7.7 \%$ within assay and $9.1 \%$ between assays.

Glucagon was assayed by a commercial kit (Double Antibody Glucagon ${ }^{\circledR}$, Diagnostic Products Corporation) following the manufacturer's instructions. The detection limit of the assay as calculated by the Riasmart software was $8.9 \pm 1.6 \mathrm{pg} / \mathrm{ml}$. The coefficients of variation were $4.1 \%$ within assay and $8.3 \%$ between assays.

Circulating growth hormone (bGH) was measured by a homologous double antibody RIA, using a highly purified bGH preparation (AFP 11182 B) both as the standard and tracer. The tracer was prepared following the methods described by Salacinski et al. (1981) and $10000 \mathrm{cpm}$ of the 125I-bGH solution (specific activity: $28.6 \mu \mathrm{Ci} / \mu \mathrm{g}$ ) obtained were added to each assay tube. The antiserum was raised in the rabbit against bGH (NIH-GH-B13) and used at the final dilution of $1 / 17500$. The antiserum showed a cross-reactivity of $0.1 \%$ with bovine prolactin and less than $0.01 \%$ with other pituitary hormones. Separation of free hormone from hormone-antibody complexes was achieved using an anti-rabbit gammaglobulin serum raised in the goat at the final dilution of $1 / 600$. The detection limit of the assay as calculated by the Riasmart software was $260 \pm 39.6 \mathrm{pg} / \mathrm{ml}$ and the precision of the analysis expressed as coefficient of variation was $5.7 \%$ within assay and $8.8 \%$ between assays.

Commercial enzymatic-colorimetric kits were used to determine plasma concentration of glucose (Peridochrom Glucose ${ }^{\circledR}$, Boehringer, Mannheim, Germany), urea (Urea Colour ${ }^{\circledR}$; 
Boehringer) and NEFA (NEFA Quick ${ }^{\circledR}$; Boehringer), according to the manufacturer's instructions.

\section{Statistical analysis}

The haematocrit within each experiment underwent analysis of variance (ANOVA) (SAS, 1988), considering animal and sampling time as sources of variation.

The basal concentrations of hormones and metabolites were calculated as the mean of the concentrations measured in the three samples collected before the beginning of the infusions $(-120,-60$ and $0 \mathrm{~min})$. These values were submitted to ANOVA (SAS, 1988) considering animal, day of sampling, treatment and physiological phase as sources of variation, according to the experimental design. Within each physiological phase, the effect of the day of sampling was considered to evaluate possible carry-over effects due to the treatment administered the day before.

The responses of hormones and metabolites to the different infusions were studied as variations from the basal value considering the basal concentration equal to 100 . Then, the area under the curve (AUC) was calculated and submitted to ANOVA (SAS, 1988), considering treatment, animal, day of sampling and physiological phase as sources of variation.

Mean differences within factors were analysed by Tukey's test (SAS, 1988). Finally, the correlations (SAS, 1988) between the blood concentrations of hormones and metabolites were also studied.

\section{Results}

The leptin concentration values of the four bovine plasma samples used in the parallelism test were linearly related to the plasma volume and showed an acceptable degree of parallelism with the standard curve (Table 2). However, the angular coefficients of the correlation curves between expected and observed leptin concentrations indicated that the sensitivity of the kit for bovine leptin was rather low.

The haematocrit measured at $-120,0,120,240$ and $360 \mathrm{~min}$ from the beginning of infusions ranged between 39 and $43 \%$

Table 2. Parallelism test performed in four different bovine plasma samples. Each test was performed in triplicate and repeated at least three times

\begin{tabular}{|c|c|c|c|c|c|c|c|c|c|c|c|c|}
\hline \multirow[b]{2}{*}{$\begin{array}{l}\text { Sample volume } \\
(\mathrm{ml})\end{array}$} & \multicolumn{3}{|c|}{ Sample 1} & \multicolumn{3}{|c|}{ Sample 2} & \multicolumn{3}{|c|}{ Sample 3} & \multicolumn{3}{|c|}{ Sample 4} \\
\hline & $\begin{array}{l}\text { Observed } \\
\text { (ng/ml) }\end{array}$ & $\mathrm{CV}$ & $\begin{array}{l}\text { Expected } \\
(\mathrm{ng} / \mathrm{ml})\end{array}$ & $\begin{array}{l}\text { Observed } \\
(\mathrm{ng} / \mathrm{ml})\end{array}$ & $\mathrm{CV}$ & $\begin{array}{l}\text { Expected } \\
(\mathrm{ng} / \mathrm{ml})\end{array}$ & $\begin{array}{c}\text { Observed } \\
(\mathrm{ng} / \mathrm{ml})\end{array}$ & $\mathrm{CV}$ & $\begin{array}{l}\text { Expected } \\
(\mathrm{ng} / \mathrm{ml})\end{array}$ & $\begin{array}{l}\text { Observed } \\
(\mathrm{ng} / \mathrm{ml})\end{array}$ & $\mathrm{CV}$ & $\begin{array}{l}\text { Expected } \\
(\mathrm{ng} / \mathrm{ml})\end{array}$ \\
\hline 0.025 & 1.10 & 5.5 & 0.53 & 1.41 & 5.2 & 0.86 & 2.03 & 8.8 & 1.19 & 4.80 & 4.5 & 2.25 \\
\hline 0.050 & 1.33 & 1.5 & 1.05 & 1.85 & 2.9 & 1.72 & 2.78 & 2.5 & 2.37 & 6.01 & 3.2 & 4.50 \\
\hline 0.075 & 1.74 & 2.3 & 1.58 & 2.82 & 1.1 & 2.58 & 3.38 & 3.4 & 3.56 & 7.41 & 3.6 & 6.75 \\
\hline 0.100 & 2.10 & 7.6 & 2.10 & 3.44 & 4.9 & 3.44 & 4.74 & 8.6 & 4.74 & 9.00 & 4.6 & 9.00 \\
\hline $\mathrm{R}$ & & 0.994 & & & 0.991 & & & 0.983 & & & 0.998 & \\
\hline $\mathrm{a}$ & & 0.647 & & & 0.820 & & & 0.737 & & & 0.622 & \\
\hline b & & 0.715 & & & 0.617 & & & 1.050 & & & 3.300 & \\
\hline
\end{tabular}

$\mathrm{R}$, correlation coefficient of the regression curve; a, pendence of the regression curve; $b$, intercept of the regression curve.

Table 3. Basal plasma concentrations of hormones and metabolites (mean \pm SEM) measured in different physiological phases

\begin{tabular}{|c|c|c|c|}
\hline & \multicolumn{3}{|c|}{ Physiological phase } \\
\hline & 36th week of pregnancy & 2nd week of lactation & 12th week of lactation \\
\hline Leptin (ng/ml) & $2.9 \pm 0.2$ & $3.3 \pm 0.3$ & $3.2 \pm 0.2$ \\
\hline Insulin $(\mu \mathrm{U} / \mathrm{ml})$ & $10.2 \pm 0.5^{\mathrm{B} .}$ & $7.2 \pm 0.5^{\mathrm{A}}$ & $7.3 \pm 0.8^{\mathrm{A}}$ \\
\hline Glucagon $(\mathrm{pg} / \mathrm{ml})$ & $56.5 \pm 2.2^{\mathrm{C} .}$ & $48.6 \pm 1.5^{\mathrm{B} .}$ & $41.7 \pm 2.1^{\mathrm{A}}$ \\
\hline $\mathrm{GH}(\mathrm{ng} / \mathrm{ml})$ & $1.7 \pm 0.2$ & $2.5 \pm 0.1$ & $2.7 \pm 0.3$ \\
\hline Glucose $(\mathrm{mg} / \mathrm{dl})$ & $63.6 \pm 0.8$ & $60.0 \pm 1.8$ & $64.0 \pm 1.5$ \\
\hline Urea $(\mathrm{mg} / \mathrm{dl})$ & $30.5 \pm 1.4^{\mathrm{A}}$ & $28.0 \pm 1.1^{\mathrm{A}}$ & $35.0 \pm 1.1^{\mathrm{B}}$ \\
\hline NEFA $(\mu \mathrm{Eq} / 1)$ & $570.6 \pm 105.7^{\text {B. }}$ & $665.6 \pm 95.8^{\mathrm{B}}$ & $285.6 \pm 41.0^{\mathrm{A}}$ \\
\hline
\end{tabular}

Different letters in the same row indicate significantly different means $(P<0.05$; Tukey's test).

Table 4. Correlation coefficients $(r)$ between baseline concentrations of hormones and metabolites measured in late pregnancy and early lactation

\begin{tabular}{|c|c|c|c|c|c|c|c|}
\hline & Glucose & Insulin & GH & Glucagon & Urea & NEFA & Body weight \\
\hline Leptin & 0.213 & 0.140 & -0.005 & -0.259 & -0.377 & -0.267 & -0.037 \\
\hline Glucose & & $0.592 * * *$ & -0.148 & -0.172 & -0.040 & $-0.499 * *$ & 0.351 \\
\hline Insulin & & & $-0.424 * *$ & 0.388 & -0.169 & -0.332 & $0.579 * *$ \\
\hline GH & & & & $-0.480^{* *}$ & 0.182 & -0.024 & $-0.546^{* *}$ \\
\hline Glucagon & & & & & 0.107 & $0.481^{* *}$ & $0.568 * *$ \\
\hline Urea & & & & & & -0.006 & -0.031 \\
\hline NEFA & & & & & & & -0.046 \\
\hline
\end{tabular}

The asterisks indicates statistically significant $\mathrm{r}\left({ }^{*} P<0.05 ; * * P<0.01 ; * * * P<0.001\right)$. 
Table 5. Correlation coefficients $(r)$ between the concentrations of hormone and metabolite measured in late pregnancy and early lactation during the infusions

\begin{tabular}{lccccc}
\hline & Glucose & Insulin & GH & Glucagon & Urea \\
\hline Leptin & 0.217 & 0.139 & -0.031 & -0.285 & -0.381 \\
Glucose & & $0.665^{* * *}$ & -0.188 & -0.238 & -0.049 \\
Insulin & & $-0.456^{*}$ & 0.270 & $-0.500^{* *}$ \\
GH & & & $-0.580^{* *}$ & -0.053 & 0.274 \\
Glucagon & & & -0.149 & 0.036 \\
Urea & & & & $-0.529 * *$ \\
\hline
\end{tabular}

The asterisks indicates statistically significant $\mathrm{r}(* P<0.05 ; * * P<0.01 ; * * * P<0.001)$.

Table 6. Area under the curve (AUC) of hormone and metabolite profiles during the infusions. Before calculating AUC, concentration values were transformed as percentage of their basal values (equal to 100)

\begin{tabular}{|c|c|c|c|c|c|c|c|c|c|c|}
\hline & \multicolumn{3}{|c|}{ 36th week of pregnancy } & \multicolumn{3}{|c|}{ Second week of lactation } & \multicolumn{3}{|c|}{ 12th week of lactation } & \multirow{2}{*}{$\begin{array}{c}\text { Cumulative } \\
\text { SD }\end{array}$} \\
\hline & Ctrl & Glu & AA & Ctrl & Glu & $\mathrm{AA}$ & Ctrl & Glu & AA & \\
\hline Leptin & 37389 & 34862 & 36278 & 36742 & 33727 & 35778 & 33644 & 36737 & 33309 & 2777 \\
\hline Insulin & $34279^{\mathrm{A}}$ & $142645^{\mathrm{B}}$ & $80422^{\text {A. }}$ & $39465^{\mathrm{A}}$ & $200644^{\mathrm{BC} .}$ & $63998^{\mathrm{A}}$ & $36902^{\mathrm{A}}$ & $262717^{\mathrm{C}}$ & $56283^{\mathrm{A}}$ & 85511 \\
\hline Glucagon & $36669^{\mathrm{BC}}$ & $22666^{\mathrm{A}}$ & $76664^{\mathrm{D} .}$ & $47692^{\mathrm{B}}$ & $29125^{\mathrm{A}}$ & $53656^{\mathrm{BC}}$ & $40121^{\mathrm{BC}}$ & $30152^{\mathrm{AB}}$ & $60668^{\mathrm{CD}}$ & 18899 \\
\hline $\mathrm{GH}$ & 42577 & 59807 & 61888 & 41446 & 45939 & 65817 & 77438 & 36936 & 40078 & 29344 \\
\hline Glucose & $35632^{\mathrm{A}}$ & $69302^{\mathrm{B}}$ & $38791^{\mathrm{A}}$ & $34350^{\mathrm{A}}$ & $10227^{\mathrm{B}}$ & $35744^{\mathrm{A}}$ & $35106^{\mathrm{A}}$ & $133380^{\mathrm{B}}$ & $38553^{\mathrm{A}}$ & 39861 \\
\hline Urea & $30889^{\mathrm{A}}$ & $30029^{\mathrm{A}}$ & $34086^{\mathrm{AB}}$ & $33726^{\mathrm{AB}}$ & $33047^{\mathrm{A}}$ & $37294^{\mathrm{B}}$ & $36191^{\mathrm{B}}$ & $30391^{\mathrm{A}}$ & $38638^{\mathrm{B}}$ & 3590 \\
\hline NEFA & 24306 & 24179 & 26846 & 20492 & 13555 & 19035 & 27157 & 13692 & 20583 & 8822 \\
\hline
\end{tabular}

Different letters in the same row indicate significantly different means $(P<0.05$; Tukey's test).

Ctrl, control; Glu, glucose infusion; AA, amino acid infusion.

without any significant difference within animal indicating that no haemodilution occurred during the experiments.

Within each physiological phase, the basal concentrations of all the endocrine and metabolic parameters were not significantly different among the three sampling days, showing no carry-over effects.

The body weight was $787 \pm 27 \mathrm{~kg}, 699 \pm 41 \mathrm{~kg}$ and $723 \pm 37 \mathrm{~kg}$ (mean \pm SEM) at the 36 th week of pregnancy and at the second and 12th week of lactation, respectively.

Basal plasma concentrations of hormones and metabolites measured at the 36th week of pregnancy and at the second and 12th week of lactation are shown in Table 3 . The basal plasma concentrations of insulin, glucagon, urea and NEFA were significantly different $(P<0.05)$ between the physiological phases. Blood insulin was higher at the 36th week of pregnancy, decreased after parturition $(P<0.05)$ and remained stable until the 12 th week of lactation. Glucagon showed a progressive and significant decrease $(P<0.05)$ from the dry period to the 12th week of lactation. Plasma GH tended to be higher in early lactation than at week 36 of pregnancy, but the difference did not reach the minimum threshold of statistical significance. As expected, circulating NEFA were higher $(P<0.05)$ in late pregnancy and at the second week of lactation. Finally, plasma urea was significantly more concentrated $(P<0.05)$ at the 12th week of lactation.

No significant correlations between leptin, body weight and other hormones and metabolites were found either for basal concentration (Table 4) or for those measured during the infusions (Table 5).

Hormone and metabolite responses observed during the infusions were analysed by studying their AUC (Table 6). As expected, the infusion of the glucose solution significantly increased $(P<0.001)$ circulating glucose two- to three-fold during the first $30 \mathrm{~min}$ Then, plasma glucose ranged between two- and 5.5-fold its basal level throughout the infusion period. The administration of the amino acid solution did not affect the circulating glucose that was similar to the control. Within each treatment, no differences were observed among physiological phases.

The variations of plasma leptin concentrations measured during the infusions are shown in Fig. 1. The infusion of both glucose or amino acid solutions did not significantly affect plasma leptin concentrations in all physiological phases.

The insulin AUC was significantly greater $(P<0.001)$ when animals were infused with the glucose solution and within this treatment, the insulin response increased progressively from the dry period to the 12th week of lactation. When the cows were infused with the amino acid solution the insulin response was always not significantly greater than the controls, and differences among the physiological phases were not observed.

The greatest glucagon AUC was observed in the case of the infusion with the amino acid solution and the smallest when infusing the glucose solution $(P<0.001)$. The glucagon response to the glucose infusion did not vary between the physiological phases. When the cows were administered with the amino acid solution, the greatest glucagon response was recorded at the 36th week of pregnancy.

The GH response was very variable among animals, and AUC was not affected by treatments and physiological phase.

In comparison with the control, glucose infusion significantly reduced the urea response only at the 12 th week of lactation. The urea response to amino acid administration increased during lactation. 

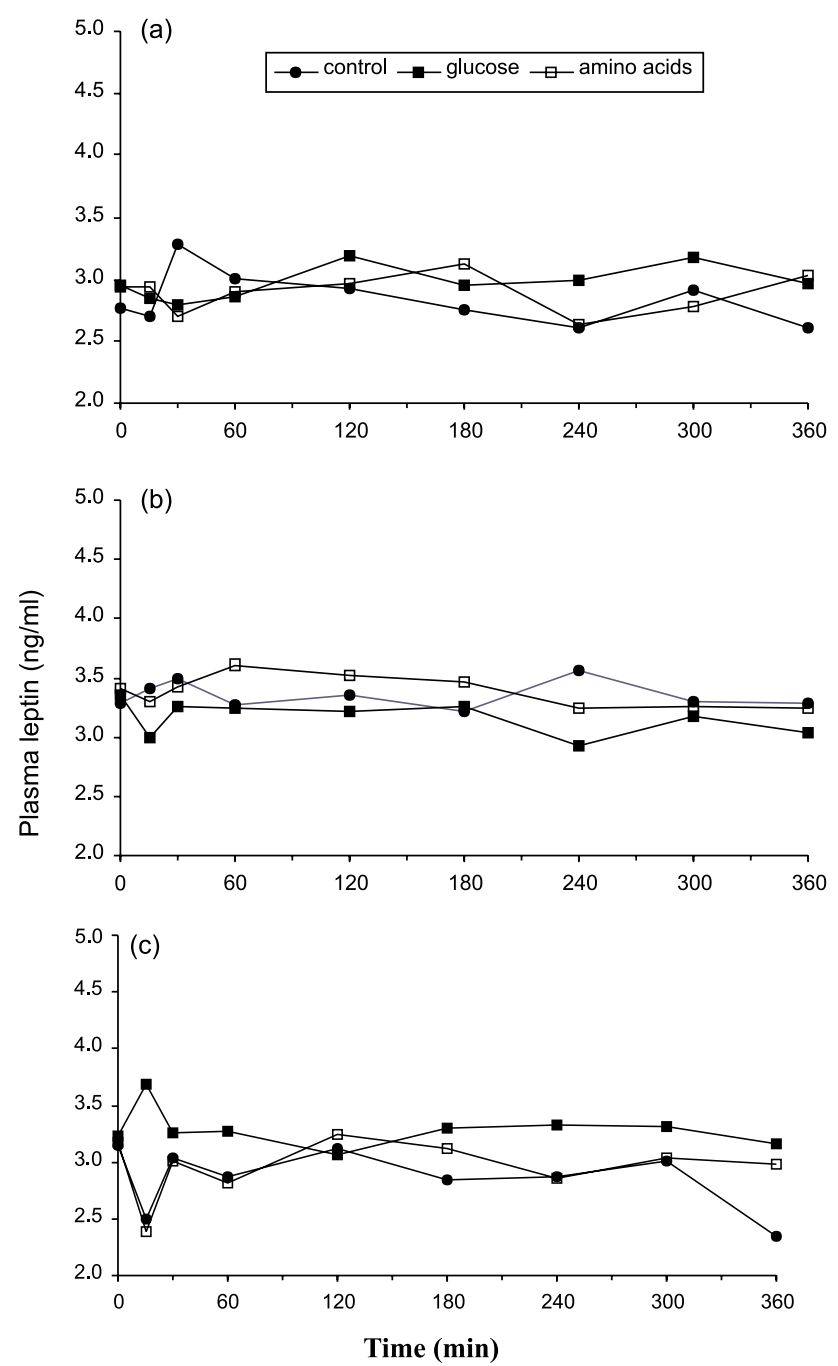

Fig. 1. Variation of plasma leptin observed during $6 \mathrm{~h}$ infusions of either saline, glucose, or a combination of essential amino acids at week 36 of pregnancy (a), and weeks 2 (b) and 12 (c) of lactation. At time 0 a bolus of glucose or amino acids was injected and the infusions started. Infusion rate was increased by $15 \%$ at $120 \mathrm{~min}$ and by another $15 \%$ at $240 \mathrm{~min}$ (see Material and methods for details). The cumulative standard deviation was $0.7 \mathrm{ng} / \mathrm{ml}$.

The reduction of plasma NEFA concentrations was more closely associated with food administration than infusions and treatments did not significantly affect the NEFA AUC. The decrease of plasma NEFA concentrations was not significantly different among the physiological phases, even though glucose infusion produced a more pronounced reduction of circulating NEFA during lactation.

\section{Discussion}

The high concentrations of leptin observed in pregnant and lactating women and in female rodents support the hypothesis that leptin plays an important role in nutrient partitioning during pregnancy and lactation (Mukherjea et al., 1999).

In humans and rodents, plasma leptin increases during pregnancy and it decreases after parturition. In late pregnancy, the increase of plasma leptin was up to 25 -fold in the mouse, 2.7-fold in human and 1.8-fold in the rat (Ashworth et al., 2000). In humans, plasma leptin was lower during lactation than in pregnancy but it was higher in lactating women than in not pregnant and not lactating subjects (Mukherjea et al., 1999). In rats, serum leptin significantly increased as pregnancy advanced, it decreased following parturition and remained stable during lactation (Amico et al., 1998).

As far as is known, information about the variations of circulating leptin in pregnancy and lactation in ruminants is rather scarce. Recently, Accorsi et al. (2000) reported on the variation of plasma leptin in Friesian cows throughout the lactation cycle using the same Multi Species RIA. Those authors measured the minimum leptin concentrations (on average $1.8 \mathrm{ng} / \mathrm{ml}$ ) between day 5 before calving and day 10 postpartum and they consider this low value as a potential signal to the hypothalamus of the animal's negative energy balance. Then, plasma leptin increased significantly after 4-5 months of lactation $(3.5 \mathrm{ng} / \mathrm{ml})$.

The variations of basal plasma concentrations of hormones and metabolites observed in the present work are consistent with the authors' previous findings on the Italian Simmental cow (Prandi et al., 1992). These differed from those of Accorsi et al. (2000), as no reduction of plasma leptin at the beginning of lactation was observed. The Italian Simmental cow is a dual-purpose breed and displays a lower attitude in mobilizing body reserves than the Friesian cow, because of a less negative energy balance around parturition. Moreover, the Italian Simmental cow recovers faster from the energy deficit in early lactation (see Bono, 1997). The metabolic differences between the two breeds may explain in part the different pattern of leptin release, and support the hypothesis that the energy balance may affect leptin release.

In the present study, plasma leptin was measured by a commercial Multi Species RIA which used an antibody raised against human leptin. Some authors (Blache et al., 2000; Delavaud et al., 2000; Ehrhardt et al., 2000) compared their RIA systems specifically developed for ruminants with the Multi Species RIA and concluded that some insensitivity exists within the Multi Species RIA in the lower range of leptin concentrations when used for ovine plasma samples. The correlations found between the two systems were always low although highly significant, and the results obtained by the two RIA systems in sheep showed the same physiological variations (Delavaud et al., 2000). It is interesting to note that Blache et al. (2000) and Ehrhardt et al. (2000) developed their RIAs using recombinant bovine leptin as a tracer and for raising the antibody, since there are only two amino acid differences between the mature forms of bovine and ovine leptin (Blache et al., 2000).

Ehrhardt et al. (2000) compared their bovine RIA and the Multi Species RIA also using cattle plasma. They observed that in growing cattle plasma the leptin concentrations measured with their bovine leptin RIA were higher than those measured by the Multi Species RIA, but they did not observed any relationship between them. However, the plasma leptin concentrations measured by Ehrhardt et al. (2000) in dairy cows in late lactation (range: $3.5-5.5 \mathrm{ng} / \mathrm{ml}$ ) using their specific RIA are not very different from those reported by others who used the Multi Species RIA in Friesian cows at 190 days of lactation (4.07 $\pm 0.21 \mathrm{ng} / \mathrm{ml}$; Rosi et al., 1999), at month 4-5 of lactation (average: $3.5 \mathrm{ng} / \mathrm{ml}$; Accorsi et al., 2000) and at 90-110 days of lactation $(3.84 \pm 0.45 \mathrm{ng} / \mathrm{ml}$; Rosi, unpub- 
lished data). In addition, they made the comparison between the two RIAs using 10 plasma samples from growing cattle and the concentrations they measured did not seem very dispersed, as suggested by the low standard error observed. It is possible that a significant correlation between the two RIA methods may result if examining a broader distribution of cattle plasma leptin concentrations.

In the parallelism test performed in the present study, leptin concentration values of the four bovine plasma samples were linearly related to plasma volume indicating that the antibody cross-reacted with bovine leptin. However, the angular coefficients of the correlation curves between expected and observed leptin concentrations were always lower than one, indicating a low sensitivity of the kit for bovine leptin.

Those findings indicate that the Multi Species RIA has a lower sensitivity for ruminant leptin and, consequently, this low sensitivity may contribute to the lack of significant leptin variations observed in this study. Nevertheless, as a low variability was observed both within assay and between assays, the Multi Species kit may be used to detect large variations of circulating leptin in cattle.

A factor which may have influenced the basal leptin concentrations was that the infusions were performed on three consecutive days. To exclude any carry-over effect, the effects of the sampling day within each physiological phase were studied without finding any significant difference. This suggested that the basal concentrations of hormones and metabolites were not affected by the treatment administered the day before.

To evaluate the effect of the treatments, an experimental design was developed that would induce very high, possibly maximal, response that should be consistent among the tested animals. Moreover, a Latin square design was adopted which is very sensitive for the evaluation of the different sources of variation even when there are few experimental animals but a protocol with repeated measurements is adopted (Kirk, 1968).

The short-term variations of circulating leptin, both circadian and in response to a metabolic stimulation, are rather large. On average, they ranged from 7 to $11 \mathrm{ng} / \mathrm{ml}$ in the mouse (Ahren, 2000), from 2.6 to $8.7 \mathrm{ng} / \mathrm{ml}$ in the rat (Pickavance et al., 1998) and from 2.3 to $4.9 \mathrm{ng} / \mathrm{ml}$ in humans (Van Aggel-Leijssen et al., 1999). In humans, plasma leptin showed a one-third increase after $6 \mathrm{~h}$ insulin infusion (Malmstrom et al., 1996).

There are few data about the circadian variations of circulating leptin in ruminants, even though one may expect variations of magnitude similar to that observed in other species. In male sheep, the baseline concentration of leptin did not vary during the $24 \mathrm{~h}$ and plasma leptin did not show the increase observed during the night in the other species (Blache et al., 2000). Those authors suggested that biological rhythms that govern leptin variations apparently differ between monogastric and ruminants. Consistent with those findings, no significant plasma leptin variations from 0700 to $1500 \mathrm{~h}$ were observed in dairy cows in late pregnancy and early lactation.

Leptin release is regulated by factors other than adiposity and the homeostasis modification of some metabolites may affect it. For instance, glucose transport and metabolism are implicated in the regulation of leptin expression and secretion in rats (Mueller et al., 1998) and humans (Wellhoener et al., 2000). Moreover, leptin synthesis and release seem to be stimulated by insulin in human and rodents (Houseknecht et al., 1998), and hyperinsulinaemia increased circulating leptin within hours, even though each species exhibits a different response (Saladin et al., 1995; Vidal et al., 1996). In particular, a significant increase of plasma leptin concentration was observed after $6 \mathrm{~h}$ of insulin infusion (Malmstrom et al., 1996) in humans, whereas a $2 \mathrm{~h}$ infusion was insufficient (Larsson et al., 1996). In normal mice, Mizuno et al. (1996) observed that leptin mRNA increased approximately two-fold at $30 \mathrm{~min}$ after the intraperitoneal injection of either glucose or insulin.

So far, the effects of glucose and insulin in the acute regulation of leptin release have been less investigated in ruminants. Using the Multi Species RIA, Delavaud et al. (1999) found a slight but significant increase of plasma leptin in dry cows from 1.97 to $2.43 \mathrm{ng} / \mathrm{ml}$ after food administration, but they did not find any relationship between the postprandial variations of plasma insulin and leptin. Consistently, Kauter et al. (2000) investigated the effect of glucose, adrenaline, insulin or glucagon in regulating plasma leptin in sheep and found that a single injection of glucose or hormones which affect blood glucose did not stimulate leptin secretion. In contrast, it has been found that insulin stimulated leptin gene expression in vitro in subcutaneous adipose tissue from castrated male cattle (Houseknecht et al., 2000).

In the present study, the infusion of glucose resulted in a two- to 5.5-fold glycaemia increase that was maintained for $6 \mathrm{~h}$ and, as expected, it elicited a massive pancreatic response in all physiological phases, but leptin release was not significantly affected. Although the results of the present study seemed to indicate that glucose and insulin do not acutely stimulate leptin release as observed by Delavaud et al. (1999) and Kauter et al. (2000), it is not possible to exclude the possibility that glucose and/or insulin effects on leptin release may be modulated by the energy status of the animals.

In this study, the insulin AUC after glucose infusion significantly increased from the dry period to lactation, and this seems to be in contrast to insulin resistance observed in the dairy cow around parturition, when insulin secretion and pancreatic sensitivity to insulinotropic stimuli are reduced (Lomax et al., 1979; Sartin et al., 1985; Staufenbiel et al., 1992). In the present experiment, the response of pancreatic $\beta$-cells to a prolonged insulinotropic stimulation was measured as a percentage of the basal insulin concentration. The response to glucose was lower at the 36th week of pregnancy, when insulin basal concentrations were significantly higher. It is possible that the amount of glucose infused at that time was not sufficient to induce the maximum pancreatic response, as happened in early lactation when the pancreatic $\beta$-cells response progressively increased during from week 2 to week 12 of lactation. In addition, the present experiment was performed using Italian Simmental cows, which are characterized by a lower attitude in mobilizing body reserves than Friesian cows (Bono, 1997).

Little information appears to be available about the effects of amino acids on leptin release. In the present study, the infusion of essential amino acids significantly stimulated glucagon release without affecting plasma leptin, and these results are consistent with those of Bennek et al. (1999), who failed to acutely modulate leptin release in young humans by infusing arginine.

Growth hormone did not vary significantly among the physiological phases. This result was not completely surprisingly, as in a study on the Italian Simmental cow Prandi et al. 
(1992) found that plasma GH variations around parturition were low in comparison with those referred for the Friesian cow (Bono, 1997).

The response of GH to metabolic stimuli is controversial. In mammals, GH release seems to be stimulated by amino acids and hypoglycemia, whereas it is inhibited by hyperglycemia (Bennet and Whitehead, 1983). Kasai et al. (1980) induced a dose-dependent $\mathrm{GH}$ release in humans by administering glycine intravenously. On the contrary, Bennek et al. (1999) failed to detect an acute $\mathrm{GH}$ response in young human subjects infused with arginine. In the study of Sartin et al. (1985), GH response to glucose infusion was absent in non-pregnant nonlactating cows and minimal in late pregnancy, and the glucose infusion induced the most significant $\mathrm{GH}$ response at day 5 postpartum, even though this latter finding was more related to the drop of glucose concentration observed at the end of the infusion. Finally, the drop of circulating NEFA was recognized as a potent stimulus for GH release in the lactating cow (Reynaert et al., 1975). In the present study, circulating GH did not show any relationship with either glucose or amino acid infusions. It is possible that the variability of GH release observed among the animals masked the effects of the physiological phase and infusion on GH and, in turn, leptin release.

Taken together, these findings indicated that leptin release is not acutely affected by glucose and amino acid availability, and no short-term relationship exists between insulin, glucagon and GH and leptin release in Italian Simmental cows during the dry period and early lactation.

\section{Acknowledgements}

The present experiment was supported by the Italian National Research Council (C.N.R) - special project R.A.I.S.A. Bovine growth hormone (AFP 11182 B) for iodination was kindly supplied by Dr A. F. Parlow, Pituitary Hormones and Antisera Centre, UCLA Medical Centre, CA, USA. We are particularly grateful to $\mathrm{Mr}$ Tommaso Brogin for his skilled and reliable technical assistance and Mr Vittorino Carli (Istituto Zooprofilattico delle Venezie) for preparing the injectable amino acid solution. We also thank the Director and staff of the experimental dairy farm 'Marianis' (Regional Board for the Agricultural Development of the Region Friuli Venezia Giulia, I-E.R.S.A) for their help and in particular Dr Guido Rumiz, DVM, for his valuable contribution. Finally, we are particularly in debt with Dr Guido Guidetti and Dr Emanuela Ragno for their irreplaceable help in data elaboration.

\section{References}

Accorsi, P. A., N. Govoni, B. Pacioni, C. Pezzi, A. Parmeggiani, and R. Gaiani, 2000: Variazioni della concentrazione plasmatica della leptina e di altri ormoni metabolici in vacche da latte a diversi stadi di lattazione. Proceedings Annual Meeting Società Italiana Delle Scienze Veterinarie LIV, 65-66.

Ahren, B., 2000: Diurnal variation in circulating leptin is dependent on gender, food intake and circulating insulin in mice. Acta Physiol. Scand. 169, 325-331.

Amico, J. A., A. Thomas, R. S. Crowley, and L. A. Burmeister, 1998: Concentration of leptin in the serum of pregnant, lactating, and cycling rats and of leptin messenger ribonucleic acid in rat placental tissue. Life Sci. 63, 1387-1395.

Ashworth, C. J., N. Hoggard, L. Thomas, J. G. Mercer, J. M. Wallace, and R. G. Lea, 2000: Placental leptin. Rev. Reprod. 5, 18-24.

Bauman, W. A., A. M. Spungen, Y. G. Zhong, and C. V. Mobbs, 1996: Plasma leptin is directly related to body adiposity in subjects with spinal cord injury. Hormone Metabolic Res. 28, 732-736.
Bennek, C., I. Gehrt, A. Keller, E. Keller, J. Kratzsch, F. W. Blum, and W. Kiess, 1999: Arginine infusion and/or acute changes of growth hormone levels do not acutely alter leptin serum levels. J. Pediatr. Endocrinol. Metab. 12, 847-851.

Bennett, G. W., and S. A. Whitehead, 1983: Mammalian Neuroendocrinology. pp. 162-167. Oxford University Press, New York, USA. Blache, D., R. L. Tellam, L. M. Chagas, M. A. Blackberry, P. E. Vercoe, and G. B. Martin, 2000: Level of nutrition affects leptin concentrations in plasma and cerebrospinal fluid in sheep J. Endocrinol. 165, 625-637.

Boden, G., X. Chen, M. Mozzoli, and I. Ryan, 1996: Effect of fasting on serum leptin in normal human subjects. J. Clin. Endocrinol. Metab 81, 3419-3423.

Bono, G., 1997: Lactation and the resumption of reproductive activity during the postpartum period in high yielding dairy cows. AgroCiencias 13, 19-29.

Delavaud, C., F. Bocquier, Y. Chilliard, D. H. Keisler, A. Gertler, and G. Kann, 2000: Plasma leptin determination in ruminants: effect of nutritional status and body fatness on plasma leptin concentration assayed by a specific RIA in sheep. J. Endocrinol. 165, 519-526.

Delavaud, C., Y. Faulconnier, F. Bocquier, and Y. Chilliard, 1999: Pre- and postprandial changes in plasma leptin and insulin concentrations during underfeeding and refeeding in dry cows. Proc. Nutr. Soc. 59, 108A.

Ehrhardt, R. A., R. M. Slepetis, J. Siegal-Willott, M. E. Van Amburgh, A. W. Bell, and Y. R. Boisclair, 2000: Development of a specific radioimmunoassay to measure physiological changes of circulating leptin in cattle and sheep. J. Endocrinol. 166, 519-528.

Hart, I. C., 1983: Endocrine control of nutrient partitioning in lactating ruminants. Proc. Nutr Soc. 42, 181-194.

Havel, P. J., R. Townsend, L. Chaump, and K. Teff, 1999: High-fat meals reduce 24-h circulating leptin concentrations in women. Diabetes 48, 334-341.

Houseknecht, K. L., C. A. Baile, R. L. Matteri, and M. E. Spurlock, 1998: The biology of leptin: a review. J. Anim. Sci. 76, 1405-1420.

Houseknecht, K. L., C. P. Portocarrero, S. Ji, R. Lemenager, and M. E. Spurlock, 2000: Growth hormone regulates leptin gene expression in bovine adipose tissue: correlation with adipose IGF-1 expression. J. Endocrinol. 164, 51-57.

Kasai, K., H. Suzuki, T. Nakamura, H. Shiina, and S. I. Shimoda, 1980: Glycine stimulated growth hormone release in man. Acta Endocrinol. Copenh. 93, 286-283.

Kauter, K., M. Ball, P. Kearney, R. Tellam, and J. R. McFarlane, 2000: Adrenaline, insulin and glucagon do not have acute effects on plasma leptin levels in sheep: development and characterisation of an ovine leptin ELISA. J. Endocrinol. 166, 127-135.

Kirk, R. E., 1968: Experimental Design: Procedures for the Behavioural Sciences. Brooks/Cole Publishers Co, Belmont, CA, USA

Larsson, H., S. Elmstahl, and B. Ahren, 1996: Plasma leptin levels correlate to islet function independently of body fat in postmenopausal women. Diabetes 45, 1580-1584.

Lomax, M. A., G. D. Baird, C. B. Mallison, and H. W. Symonds, 1979: Differences between lactating and non-lactating dairy cows concentration and secretion rate of insulin. Biochem. J. 180, 281-289.

Malmstrom, R., M. R. Taskinen, S. L. Karonen, and H. YkiJarvinen, 1996: Insulin increases plasma leptin concentrations in normal subjects and patiens with NIDDM. Diabetologia 39, 993-996.

Mizuno, T. M., H. Bergen, T. Funabashi, S. P. Kleopoulos, Y. G. Zhong, W. A. Baumann, and C. V. Mobbs, 1996: Obese gene expression-reduction by fasting and stimulation by insulin and glucose in lean mice, and persistent elevation in acquired (dietinduced) and genetic (yellow agouti) obesity. Proc. Nat. Acad. Sci. USA 93, 3434-3438.

Mueller, W. M., F. M. Gregoire, K. L. Stanhope, C. V. Mobbs, T. M. Mizuno, C. H. Warden, and P. J. Havel, 1998: Evidence that glucose 
metabolism regulates leptin secretion from cultured rat adipocytes. Endocrinology 139, 551-558.

Mukherjea, R., T. W. Castonguay, L. W. Douglass, and P. MoserVeillon, 1999: Elevated leptin concentrations in pregnancy and lactation: possible role as a modulator of substrate utilisation. Life Sci. 65, 1183-1193.

Pickavance, L., M. Tadayyon, G. Williams, and R. G. Vernon, 1998: Lactation suppresses diurnal rhythm of serum leptin. Biochem. Biophys. Res. Comm. 248, 196-199.

Prandi, A., A. Comin, G. Gabai, C. Rossi, and G. Bono, 1992: Plasma variations of some hormones and nutrients associated with the energy metabolism in high yielding Simmental cows. Arch. Vet. It. 43, 213-226.

Reidy, S. P., and J.-M. Weber, 2000: Leptin: an essential regulators of lipid metabolism. Comparative Biochem. Physiol. (Part a) 125, 285-297.

Reynaert, R., M. de Paepe, S. Marcus, and G. Peeters, 1975: Influence of serum free fatty acid levels on growth hormone secretion in lactating cows. J. Endocrinol. 66, 213-224.

Rosi, F., G., Savoini, and R. Capalbo, 1999: Dairy cow: relationships between milk and plasma leptin and productive performance. In: Piva, G., G. Bertoni, F. Masoero, P. Bani, and L.Calamari (eds), Recent Progress in Animal Production Science, Vol. 1, pp. 422-424. Publisher, Town.

Salacinski, P. R. B., C. McLean, J. E. C. Sykes, V. V. ClementJones, and P. J. Lorry, 1981: Iodination of proteins, glycoproteins and peptides using a solid phase oxiding agent 1,3,4,6-tetrachloro$3 \alpha, 6 \alpha$-diphenil glicoluril (iodogen). Analytical Biochem. 117, 136-146.

Saladin, R., P. De Vos, M. Guerre-Millo, A. Leturque, J. Girard, B. Staels, and J. Auwerx, 1995: Transient increase in obese gene expression after food intake or insulin administration. Nature 377, $527-529$.

Sartin, J. L., K. A. Cummins, R. J. Kemppainen, D. N. Marple, C. H. Rahe, and J. C. Williams, 1985: Glucagon, insulin, and growth hormone responses to glucose infusion in lactating dairy cows. Am. J. Physiol. 284, E108-E114.

SAS, 1988,: SAT/STAT User's Guide (Release 6.093). SAS Institute Inc, Cary, NC, USA.

Staufenbiel, R., U. Rischk, B. Schumacher, and W. Becker, 1992: Beurteilung der insulin- und glucoseregulation bei der milchkuh mittels tagesprofilen, dem einfachen und modifizierten glucosetoleranztest. Deutsche Tierarztliche Wochenschrift 99, 69-75.

Tsuchiya, T., Y. Nagao, A. Ozawa, M. Matsumoto, K. Sugahara, T. Kubo, and H. Kato, 1998: Decrease of the obese gene expression in bovine subcutaneous adipose tissue by fasting. Biosci., Biotechnol. Biochem. 62, 2068-2069.

Van Aggel-Leijssen, D. P. C., M. A. van Baak, R. Tenenbaum, L. A Campfield, and W. H. M. Saris, 1999: Regulation of average $24 \mathrm{~h}$ human plasma leptin level; the influence of exercise and physiological changes in energy balance. Int. J. Obesity Related Metab. Disorders 23, 1651-1658.

Vernon, R. G., 1989: Endocrine control of metabolic adaptation during lactation. Proc. Nutr. Soc. 48, 23-32.

Vidal, H., D. Auboeuf, P. De Vos, B. Staels, J. P. Riou, J. Auwerx, and M. Laville, 1996: The expression of ob gene is not acutely regulated by insulin and fasting in human abdominal subcutaneous adipose tissue. J. Clin. Invest. 98, 251-255.

Wellhoener, P., B. Fruehwald-Schultes, W. Kern, D. Dantz, W. Kerner, J. Born, H. L. Fehm, and A. Peters, 2000: Glucose metabolism rather than insulin is a main determinant of leptin secretion in humans. J. Clin. Endocrinol. Metab. 85, 1267-1271. 